\title{
John Conolly (1794-1866): The Return of the Wanderer
}

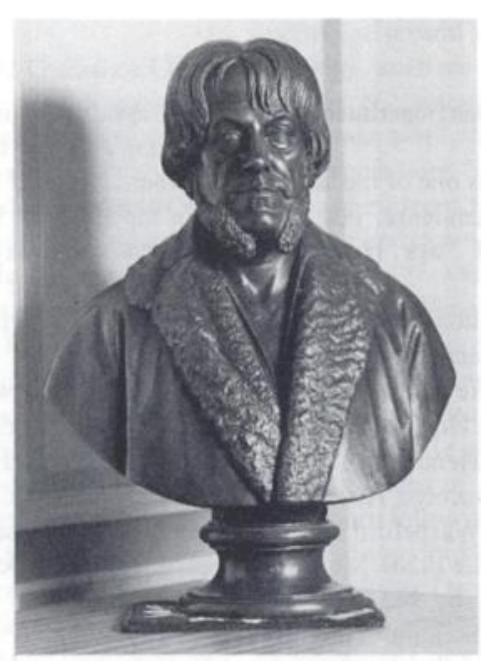

The name of John Conolly, writes his obituarist in the Journal of Mental Science [12 (1866): 146] "liveth for ever more." As a reformer he will go down in history as one of the most distinguished men of his age, to be mentioned in the same breath, say, as John Howard, Thomas Clarkson and Lord Shaftesbury. As a psychiatrist he will be identified for all time with the non-restraint system after its translation from France to England. "There is no asylum in the world," he opined, "in which all mechanical restraints may not be abolished not only with safety, but with incalculable advantage."

In his lifetime he received accolades from various distinguished academic and professional bodies. Oxford University, for example, elected him to an honorary DCL. Nearer home, in 1843, at the third annual meeting of the Association of Medical Officers of Asylums and Hospitals for the Insane, a precursor of our College, he was invited to take the chair, and for the year 1858 he was elected president, the fifth to be so honoured after that office was established in 1854.

He was visually commemorated in a portrait painted (circa 1852) by Sir John Watson Gordon, RA, and in 1866 a marble bust was executed by Benzoni-a work of art which is the occasion of this eulogy.

The following facts came to light when I was researching the history of the College: Professor (Baron) Jaromir Mundy (of Moravia), a Belgian, and a devotee of Conolly's, commissioned the bust and presented it to the Association. At that time the Association was homeless and whoever was in authority to do so handed over the bust, most unfortu- nately as a gift and not as a loan, to the Royal College of Physicians of which Conolly had been elected a fellow in 1844. In the following decades the Physicians have moved house on more than one occasion and Conolly had perforce to go along with them. Today he graces the foyer of their present palatial habitat in Regent's Park.

It was at some stage in my reading that I was transported by a sudden flight of fancy. Now that we-Conolly's professional and spiritual descendants-had a home of our own, was it not right and proper for him to share it with us? I instantly wrote to our then president, Thomas Bewley, who, with the feeling for history which he so patently has, gave my fantasy his stamp of approval. He tactfully approached the Physicians who, sadly, refused to be swayed by either fantasy or sentiment. They adopted a legalistic view: a gift was a gift, wasn't it?, they argued. What, happily, they did agree to, however, was to allow us to have a copy of the bust cast in bronze from the original.

This has now been done-and a magnificent job it has turned out to be. A suitable plinth is to be constructed, but for the moment Conolly presides over the library; and it is remarkable how well his handsome, patrician features fit in to the frame of this elegant post-Regency salon.

So it is that after well over a century of wandering, John Conolly (or his alter ego), one of our founding fathers, has come home where he rightfully belongs.

HeNRy R. Rollin Emeritus Consultant Horton Hospital, Epsom 